\title{
TATA KELOLA PEMERINTAHAN DESA PASCA IMPLEMENTASI UNDANG-UNDANG DESA
}

\author{
Oleh \\ Deden Suhendar \\ Dosen Administrasi Negara Universitas Al-Ghifari \\ email:deden_suhendar321@yahoo.co.id
}

\begin{abstract}
ABSTRAK. Meskipun desa telah diberi wewenang oleh Undang-Undang Desa untuk melakukan urusannya sendiri, dalam praktiknya sebagian besar desa yang diteliti masih cenderung bergantung pada pemerintah kabupaten. Terkait implementasi demokrasi desa, ruang artikulasi warga belum difungsikan secara optimal. BPD, sebagai wahana representasi warga belum memainkan peran yang optimal, dan tidak ada upaya untuk memperkuat peran ini baik dari BPD itu sendiri maupun oleh warga. Sehingga dapat dikatakan bahwa pemerintahan desa setelah penerapan UU Desa belum mengalami banyak perubahan. Kewenangan desa untuk membentuk Perdes juga tidak sepenuhnya digunakan. Tidak banyak perdes yang diterbitkan, selain Perdes besar seperti APBDes. Dengan otoritas penuh, lebih banyak Perdes harus dikeluarkan karena konsekuensinya adalah banyak hal akan dikelola oleh desa itu sendiri. Pola pikir kepala desa tampaknya telah menunjukkan sesuatu yang positif, dalam arti bahwa kepala desa telah mulai membuka ruang demokrasi, namun demikian perlu keberanian untuk menjalankannya tanpa perlu kekhawatiran intervensi dari pemerintah kabupaten. Rendahnya kualitas demokrasi berdampak pada kinerja pemerintah desa. Kinerja pemerintah hanya dipahami sebagai kinerja pembangunan fisik. Suara-suara dari warga mengenai kebutuhan pembangunan lain selain pembangunan fisik masih belum terakomodir. Dalam kasus Desa Sarinagen, pengembangan yang dilakukan lebih mungkin karena kemauan dan inisiatif kepala desa. Meskipun masih mengacu pada kehendak orang-orang yang disampaikan dalam Musdes, porsinya tidak signifikan.
\end{abstract}

Kata Kunci: Demokrasi, Kinerja, Pemerintah Desa

ABSTRACT. Although the village has been given authority by the Village Law to conduct its own affairs, in practice most of the villages studied still tend to depend on the district government. Related to the implementation of village democracy, the space for citizen articulation has not yet been functioned optimally. BPD, as a vehicle for the representation of citizens has not played an optimal role, and there is no effort to strengthen these roles, both from the BPD itself and by residents. So that it can be said that village governance after the implementation of the Village Law can be said to have not experienced much change. The village's authority to form Perdes is also not fully utilized. Not many perdes have been issued, other than major perdes such as the APBDes. With full authority, more perdes should be issued because the consequences will be that many matters will be managed by the village itself. The mindset of the village head seems to have shown something positive, in the sense that the village head has begun to open up democratic space, but nevertheless it takes courage to run it without the need for fears of intervention from the district government. The low quality of democracy has an impact on the performance of village governments. Government performance is only understood as physical development performance. Voices from residents regarding other development needs besides physical development are still not accommodated. In the Sarinagen case, the development carried out was more likely because of the will and initiative of the village head. Even though it still refers to the will of the people conveyed in the Musdes, the portion is not significant.

Keywords: Democration, Performance, Village Government 


\section{PENDAHULUAN}

Diundangkannya Undang-Undang (UU) Nomor 06 Tahun 2014 tentang Desa dinilai sebagai kebijakan paling progresif sepanjang sejarah perjuangan desa. Kebijakan dimaksud di antaranya terkait dengan Dana Desa sebagaimana disebut di dalam UU Desa pasal 72 yang menyatakan bahwa kini terdapat begitu banyak sumber keuangan desa dengan aturan alokasi yang cukup menjanjikan. Sumber dana dimaksud adalah pendapatan asli desa (hasil usaha, hasil aset, swadaya dan partisipasi, gotongroyong, dan lain-lain pendapatan asli Desa), APBN, hasil pajak daerah dan retribusi daerah Kabupaten/Kota (paling sedikit $10 \%$ ), alokasi dana desa (bagian dari dana perimbangan yang diterima Kabupaten/Kota dengan besaran minimal 10\% setelah dikurangi Dana Alokasi Khusus), bantuan keuangan dari APBD Provinsi dan Daerah (Kabupaten/Kota), hibah dan sumbangan yang tidak mengikat dari pihak ketiga, serta pendapatan lain-lain desa yang sah.

Untuk kewenangan berdasarkan hak asal usul desa, hak dimaksud adalah hak yang merupakan warisan yang masih hidup dan prakarsa desa atau prakarsa masyarakat desa sesuai dengan perkembangan kehidupan masyarakat; sedangkan kewenangan lokal berskala desa adalah kewenangan untuk mengatur dan mengurus kepentingan masyarakat desa yang telah dijalankan oleh desa atau mampu dan efektif dijalankan oleh desa atau yang muncul karena perkembangan desa dan prakarsa masyarakat desa seperti membuat pasar desa, saluran irigasi, dan sanitasi lingkungan; sementara kewenangan melakukan tugas pembantuan baik dari Pemerintah Pusat, Pemerintah Provinsi, atau Pemerintah Daerah Kabupaten/Kota meliputi penyelenggaraan pemerintahan desa dan pelaksanaan pembangunan desa.

Penguatan demokrasi pada level desa juga merupakan kebijakan penting lainnya yang menjadikan UU Desa dinilai memberi harapan bagi masa depan desa yang lebih baik termasuk dalam konteks proses demokratisasi. Di antaranya terkait dengan penguatan fungsi Badan Permusyawaratan Desa yang kini diberi wewenang penuh melakukan pengawasan kinerja Kepala Desa, selain ikut terlibat dalam pembahasan dan penyepakatan Rancangan Peraturan Desa dan menampung serta menyalurkan aspirasi masyarakat desa, serta adanya musyawarah desa sebagai wadah bagi keterlibatan politik warga desa yang lebih nyata.

Ketertinggalan desa kerap dianggap sebagai akibat minimnya kewenangan desa, sehingga langkah efektif untuk memajukan desa dinilai harus dimulai dari penguatan kewenangan desa. Meski kewenangan merupakan faktor penting, berbagai praktek reformasi menunjukkan bahwa kewenangan semata tidaklah cukup mengingat kewenangan baru bersifat potential power. Merujuk praktek 
reform di Kabupaten Bandung Barat misalnya, kewenangan baru dapat berbuah perubahan (actual power) ketika bertemu dengan sejumlah faktor lain, seperti kemampuan aktor membangun hubungan dengan multi aktor, kemampuan aktor untuk menghasilkan gagasan reform, yaitu apa yang disebut Giddens (1984) sebagai cability to make different, keberanian, dan motivation to action. Dalam buku bertajuk Bound to Lead: The Changing Nature of American Power (1990), Joseph Nee menyebut seluruh hal tersebut dengan istilah soft power, yang menurut Nee sama diperlukan guna memaksimalkan hard power.

Kebenaran hipotesis itu juga dapat dilihat kondisi faktual praktek pengelolaan kekuasaan di daerah, yaitu bahwa meski tiap kepala daerah memiliki kewenangan yang sama, namun tidak semua berbuah perubahan. Terkait hal itu, menarik untuk mendapatkan gambaran mengenai praktek pengelolaan kekuasaan di desa paska diberlakukannya UU Desa. Apakah kewenangan "baru" yang kini dilekatkan kepada desa dan kepala desa serta kepada BPD sebagai institusi politik desa berpengaruh pada tata kelola pemerintahan desa? Apakah kewenangan baru tersebut mampu mendorong pembangunan desa menjadi lebih progresif? Jika ya, apa yang menjadi faktor penyebab? Apakah semata karena pemberian kewenangan dan anggaran bagi desa sebagaimana diamanatkan UU Desa ataukah terdapat faktor-faktor lain?
Berangkat dari pertanyaan-pertanyaan kritis tersebut selanjutnya dirumuskan problem statement studi ini, yaitu: isu strategis yang didalami, yaitu tata kelola pemerintahan desa, keuangan dan aset desa, active citizen, desa adat, dan BUMDes; dan faktor-faktor yang mempengaruhi (push factor dan pull factor).

Sedangkan pertanyaan penelitian studi ini adalah: Bagaimana tata kelola pemerintahan desa paska implementasi UU UU No. 6/2014 tentang Desa?

\section{TINJAUAN PUSTAKA}

Melalui kebijakan desa yang baru, desa kini mendapat "energi" tambahan berupa anggaran (resources) dan kewenangan (power) sehingga upaya mendorong perubahan di desa ke arah yang lebih progresif menjadi lebih mungkin dilakukan. Keduanya memang merupakan sumber kekuatan penting, terutama power, sebagaimana diungkap Giddens dalam salah satu proposisinya dalam teori strukturasi (1984). Dalam proposisinya Giddens mengatakan, agensi (tindakan reform agen) tidak merefer kepada adanya kesengajaan atau adanya tujuan untuk melakukan tindakan (the intentions people have in doing things), akan tetapi lebih kepada kapabilitas (capability of agen) berupa kemampuan agen untuk membuat perbedaan (make different).; yang hanya mungkin dilakukan jika agen memiliki power. Hal lain yang penting, Giddens juga menegaskan bahwa power baru bermakna jika dipadukan dengan capability of agent, yang dimaksudkannya 
sebagai kemampuan agen atau aktor untuk membuat perbedaan (kemampuan aktor untuk merumuskan gagasangagasan reform (inovasi). Karenanya ketika kewenangan hanya digunakan untuk melaksanakan tugas-tugas rutin dan dilakukan dengan cara-cara biasa atau bussienes as usual, power tidak bermakna apa-apa dalam konteks hadirnya sebuah praktek baik (good practices), terlebih lagi best practices. Dalam proposisinya ia mengatakan, tindakan agen tidak akan memproduksi dan mereproduksi struktur, jika individu tidak melakukan intervensi terhadap tindakan tersebut.

Regulasi sebagai salah satu kekuatan struktural kerap memunculkan berbagai batasan- (constrain), yang boleh jadi menghambat aktor untuk bertindak termasuk untuk memproduksi praktek baik. Akan tetapi, merujuk proposisi Giddens lainnya, apakah batasan-batasan dalam regulasi UU Desa akan mempersempit ruang gerak kepala desa selaku aktor utama reform di desa sehingga terhambat untuk memproduksi praktek-praktek baik dalam tradisi berdesa, tidaklah secara otomatis terjadi. Hal itu karena dalam praktek struktur tidak selalu meng-constrain, akan tetapi dapat constraining dan enabling sekaligus. Maksudnya adalah bahwa regulasi meski memberi batasan, pada aktor-aktor tertentu (Giddens menyebutnya sebagai aktor yang memiliki hubungan dengan struktur), batasan tersebut justru mentriger dirinya untuk memproduksi energi positif, yang kemudian melahirkan gagasangagasan baru.

Keberadaan regulasi antara constraining dengan enabling mengenai hubungan-hubungan struktural agen dimaksud, untuk konteks desa misalnya, dapat berupa pengetahuan yang mendalam aktor-aktor desa (kepala desa, BPD, tokoh masyarakat, dan lain-lain) terhadap berbagai urusan desa dan kompleksitas permasalahannya mengingat urusan tersebut sudah digeluti sejak lama. Dengan demikian, tuntutan-tuntutan regulasi yang memaksa mereka melakukan suatu tindakan atau melarang melakukan tindakan tertentu, tidak akan bermakna negatif. Dari batasan-batasan tersebut bahkan dapat lahir gagasan baru yang jika dilaksanakan secara berkelanjutan dapat hadir sebagai praktek baik (good/best practices), sehingga harapan munculnya inovasi desa, tidak mungkin terkendala hanya karena kehadiran berbagai aturan. Tentu hal ini tidak terjadi pada sembarang aktor.

Giddens menyebut hal itu hanya mungkin pada aktor yang memiliki power atau kekuasaan atau kewenangan aktor dan kemampuan aktor untuk menciptakan perbedaan sebagaimana telah disebutkan serta motivation of action. Sebagai contoh aktor yang memiliki motivasi yang kuat untuk melahirkan perubahan guna memajukan desa, gagasan-gagasan reformnya tidak akan terhambat hanya oleh kehadiran berbagai aturan (regulasi). Giddens juga menyebut aspek ruang dan waktu atau ketepatan momentum dan 
konteks pada era di mana memproduksi praktek baik menjadi tren baru misalnya, kehadiran aneka regulasi (yang lama maupun baru) dan kerumitannya tidak berpengaruh banyak pada usaha-usaha aktor untuk memproduksi gagasan reform, mengingat tindakan yang terlalu strict pada regulasi (tindakan birokratis dan formalistic) tidak mendapat ruang (cenderung dinilai negatif). Begitu pula dengan ruang atau lokus yang tepat. Pada desa-desa dengan karakteristik tertentu (terbuka pada perubahan, setidaknya bersikap positif pada perubahan), kemungkinan praktekpraktek baik hadir menjadi lebih tinggi dan tidak terpengaruh (sedikit saja terpengaruh). Selain itu, meski regulasi memaksa aktor melakukan tindakantindakan tertentu dan atau tidak melakukan tindakan tertentu, regulasi sebagai sebuah kekuatan struktural tidaklah seperkasa yang dibayangkan. Giddens menyebut jangkauan kontrol regulasi atas agen (dialectic pf control) sebagai salah satu bukti bahwa regulasi itu sendiri mempunyai keterbatasan untuk dapat memaksa.

Sebagai contoh, pemerintah pusat mempunyai keterbatasan untuk dapat memantau secara detail pemberlakuan UU mengingat luasnya cakupan wilayah yang diawasi. Selain itu regulasi tidak mampu mengatur semua hal, sehingga dalam praktek, selalu terdapat kekosongan regulasi, yang bagi aktoraktor pro perubahan dapat digunakannya sebagai jalan masuk guna memungkinkan melakukan perubahan. Agensi tidak selalu tunduk pada struktur karena ia dapat meninggalkan struktur dengan mencari kesempatan dan kemungkinan keluar dari peraturan dan ketentuan yang ada karena adanya keterbatasan jangkauan kontrol rules atas agensi (dialectic of control) berupa segmental autonomy (otonomi berlaku pada segmen/lapisan tertentu) (Giddens, 1984;16).

Aktor kepala desa selaku agen utama perubahan di desa, dengan power yang dimiliki berupa kewenangan sebagai kepala desa serta kewenangan desa yang mengalami penguatan paska diberlakukannya kebijakan baru tentang desa serta bantuan dari aktor-aktor lain yang ada di desa, dan dengan dipengaruhi oleh sejumlah pull factor yang ada di dalam diri agen baik berupa kapabiliti agen (terutama kemampuan untuk make different), motivasi untuk melakukan perubahan, dan pengetahuan agen tentang desa; mampu merespon tantangan dan peluang yang dihadapi dalam pengelolaan desa.

\section{METODE PENELITIAN}

Fokus penelitian terletak pada fenomena kontemporer dalam kehidupan nyata, yaitu implementasi kebijakan desa oleh para pelaku di tingkat desa yang melahirkan tata kelola pemerintahan desa, selain memunculkan sejumlah roblematika. Sedangkan berdasarkan jumlah kasus yang diteliti, studi masuk dalam kategori studi multi kasus, yaitu mendalami kasus yang dipilih untuk memperoleh gambaran 
lengkap kompleksitas permasalahan implementasi kebijakan desa (sebagai social practice), khususnya kebijakan UU Desa, serta menemu-kenali tata kelola pemerintahandesa.

Berdasarkan ukuran kasus (bounded case), studi difokuskan untuk meneliti institusi/organisasi, yaitu institusi sosial, politik, dan sosial desa, individu (kepala desa, tokoh sosial dan politik desa, pelaku ekonomi, dan lain-lain), serta seluruh aktivitas yang melibatkan institusi maupun aktor individual yang terlibat. Sedangkan entitas yang dimaksud dalam penelitian ini adalah institusi politik, ekonomi, serta sosial desa dan masyarakat desa secara umum.

\section{Sumber Data}

Sumber data utama penelitian ini sebagaimana penelitian kualitatif umumnya adalah kata-kata dan tindakan, sementara data selebihnya seperti dokumen lebih merupakan data tambahan (Lofland dan Lofland, 1984:47). Hasil wawancara (in-depth interview), pengamatan, dan FGD akan dijadikan sebagai sumber data utama dan karenanya direkam, dibuat transkrip, serta dibuat catatan khusus. Hasil wawancara dan FGD dicatatkan di dalam form hasil wawancara dan FGD, sementara catatan pengamatan terhadap situasi dan kondisi lapangan dituliskan di dalam catatan harian peneliti.

Sedangkan jenis data dibedakan menjadi data primer dan data sekunder. Data primer berupa data yang diperoleh melalui wawancara, FGD, dan pengamatan yang dihimpun baik terhadap perkataan dan tindakan aktor dalam kasus yang diteliti; sedangkan data sekunder berupa sumber tertulis seperti koran, dokumen, foto, dan data statistik.

\section{Lokasi Penelitian dan Metode Pengumpulan Data}

Terkait dengan lokasi penelitian, studi dilakukan di 3 desa yang berada di tiga kecamatan di Kabupaten Bandung Barat, yaitu: Desa Mandalasari di Kecamatan Cikalong Wetan, Desa Nangerang di Kecamatan Cililin, dan Desa Sarinagen di Kecamatan Cipongkor. Sedangkan metode pengumpulan data dilakukan melalui indepth interview (wawancara mendalam) dan observasi.

\section{Analisis dan Validas Data}

Strategi umum analisis data dilakukan dengan mendasarkan pada proposisi yang yang telah ditetapkan untuk digunakan. Untuk melihat problematika dan praktek inovasi di desa digunakan proposisi pertama dan kedua, yaitu bahwa kekuatan struktural memiliki keterbatasan jangkauan dan bahwa kekuatan struktural tidak membatasi, mengingat struktur dapat constraining dan enabling berdasarkan hubungan yang ada antara struktur dan agen (Giddens, 1984:205). dan pengumpulan dokumen.

Sedangkan untuk menemukan faktorfaktor yang memungkinkan terjadinya tindakan agensi (enabling) atau tindakan inovatif aktor desa digunakan proposisi 
mengenai karakteristik aktor pembuat perubahan. Selain akan diuji keberlakuan proposisi teoretis dalam isu yang di dalami dan lokus studi, juga akan dieksplor faktorfaktor lain yang belum disebutkan di dalam proposisi teori strukturisasi Giddens.

Dari analisis terhadap faktor-faktor penyebab dan pendorong tersebut dirumuskan tipologi tindakan agensi, secara spesifik tindakan reform aktor desa dalam konteks implementasi kebijakan desa dalam melaksanakan tata kelola pemerintahan desa. Selain itu juga dilakukan analisis data dengan teknik yang lebih spesifik, yaitu: Analisis dan penyajian data melalui tahapan managing, reading and memorizing, describing, classifying, interpreting, dan representing and visualizing (Creswell (2007). Manajemen data dilakukan dengan mengorganisasikan data baik berupa rekaman maupun transkrip hasil wawancara guna mencermati secara saksama kata-kata, konteks, dan konsistensi data yang diperoleh untuk menemukan big ideas (Krueger, 1998), yang dilakukan dengan merekam, menyimpan, menuliskan dalam log-book atau catatan harian peneliti, dan field note (laporan lapangan). Setelah itu penulis melakukan pengkategorisasian terhadap data yang dihimpun, untuk kemudian ditafsirkan dengan menghubungkannya dengan tujuan, output, dan outcome penelitian.

Sedangkan strategi validasi data dilakukan dengan melakukan pemeriksaan keabsahan data dengan teknik triangulasi. Adapun jenis triangulasi yang digunakan adalah triangulation of measures (Newman, 1999:124-125), yaitu membandingkan dan mengecek balik derajat kepercayaan informasi yang diperoleh melalui waktu dan alat ukur yang berbeda dengan cara membandingkan data hasil pengamatan, hasil wawancara, dan FGD; membandingkan apa yang dikatakan di depan umum dengan apa yang dikatakan secara pribadi; membandingkan apa yang dikatakan orang-orang tentang situasi penelitian dengan apa yang dikatakan sepanjang waktu; membandingkan keadaan dan perspektif seseorang dengan berbagai pendapat dan pandangan masyarakat umum; membandingkan hasil wawancara dengan dokumen; dan membandingkan hasil wawancara, FGD, dan pengamatan dengan isi media tentang hal tersebut.

\section{HASIL DAN PEMBAHASAN}

\section{Tata Kelola Pemerintahan}

UU Nomor 6 Tahun 2014 (UU Desa) mengkonstruksi desa sebagai komunitas yang memiliki kewenangan untuk mengatur urusannya sendiri berdasarkan fungsi self-governing community. Berdasarkan konsep ini maka penyelenggaraan pemerintah di tingkat desa dilakukan secara mandiri dan demokratis oleh komunitas desa. Konstruksi ini terlihat dari beberapa norma dalam UU Desa yang mengatur tentang: 1) pemilihan kepala desa secara langsung oleh masyarakat desa; 2) keberadaan Badan Permusyawaratan Desa (BPD) 
sebagai lembaga keterwakilan masyarakat desa; 3) keberadaan musyawarah desa (Musdes) sebagai forum artikulasi warga desa dalam turut merumuskan kebijakan desa; 4) afirmasi terhadap warga desa untuk turut mengawasi penyelenggaraan pemerintahan desa; dan 5) pengaturan tentang kewajiban kepala desa untuk menyampaikan laporan penyelenggaraan pemerintahan desa kepada BPD dan masyarakat desa serta memberikan informasi kepada masyarakat terkait dengan tugasnya sebagai penyelenggara pemerintahan desa, melaksanakan pembangunan desa, pembinaan kemasyarakatan desa dan pemberdayaan masyarakat desa. Merujuk pada proses pembahasan UU Desa, muncul juga wacana untuk mendorong penyelenggaraan pemerintahan desa yang modern, yaitu profesional, efisien dan efektif, terbuka dan bertanggung jawab, meskipun di sisi lain tetap memelihara sistem nilai lokal.

Dalam studi yang dilakukan terkait dengan penyelenggaraan pemerintahan desa di tiga desa di tiga kecamatan di Kabupaten Bandung Barat, ditemukan data bahwa pada umumnya desa telah menjalankan prosedur demokrasi sebagaimana diatur dalam UU Desa terkait dengan fungsi self-governing community sebagaimana dimaksud di atas. Paparan lengkap tentang bagaimana seluruh prosedur demokrasi tersebut diuraikan secara detil pada bagian temuanhasil. Pada bagian ini akan dipaparkan bagaimana proses demokrasi desatersebut juga melibatkan peran serta pemerintah kabupaten. Keterlibatan peran kabupaten ini sebagai konsekwensi dari konstruksi UU Desa yang selain mengatur desa untuk menjalankan fungsi selfgoverning community juga menempatkan desa dalam bingkai local self government. Merujuk pada konstruksi ini maka selain diselenggarakan sendiri oleh komunitas desa, demokrasi desa dalam penyelenggaraan pemerintahan desa juga harus tetap dipandang sebagai bagian dari susunan dan tata cara penyelenggaraan pemerintah daerah.

Terkait dengan konstruksi hibrid antara fungsi self-governing community dan local self government, hibriditas tersebut ditandai dengan pencantuman pasal 18B ayat 2 dan pasal 18 ayat 7 UUD 1945 sebagai dasar konstitusi UU Desa. Penguatan demokrasi desa dimaksudkan untuk mendorong akuntabilitas penyelenggaraan pemerintahan desa melalui proses pengawasan dan keterlibatan masyarakat dalam perencanaan pembangunan, sehingga prioritas kebutuhan masyarakat dapat diakomodir dalam proses pembangunan yang dijalankan. Dengan demikian, jelas demokrasi desa menempatkan masyarakat desa sebagai subyek dalam proses penyelenggaraan pemerintahan desa. Jika demokrasi desa dipahami dalam konteks ini maka perwujudan demokrasi desa dapat saja menjadi tantangan tersendiri, mengingat selama ini desa masih berada dalam nuansa patrimonialisme politik yang cukup kuat. 
Mengacu pada konsep Max Weber, patrimonialisme merujuk pada bentuk pemerintahan tradisional yang dijalankan berdasarkan aturan yang ditetapkan dalam bingkai kepemimpinan kekeluargaan. Otoritas pengaturannya bersifat sangat personal-kekeluargaan dan mekanisme pemerintahan yang dijalankan bergantung pada mekanisme yang diterapkan dalam sistem kekeluargaan tersebut. Bertentangan dengan konsep patrimonialisme, menurut Weber, pemerintahan yang modern dilandaskan pada aturan yang berbasiskan pada birokrasi legal-rasional, yaitu birokrasi yang bukan saja mengedepankan individu tetapi juga mengacu pada prosedur yang dirumuskan bersama dalam suatu organisasi sehingga dapat memisahkan mana yang privat atau pribadi dan mana yang official atau resmi.

Patrimonialisme merupakan jenis pemerintahan yang dicirikan dengan adanya para pemimpin yang kuat. Kekuatan mereka bergantung pada posisi atribut kebudayaan secara spesifik termasuk di dalamnya adalah pemahaman lokal terhadap konsep kekuasaan-, agama tradisional, dan keterikatan dengan para leluhur. Kepemimpinan patrimonial tergantung secara penuh kepada dukungan klien, dan sistemnya distabilkan melalui tatanan normatif yang melegitimasikepemimpinan mereka serta melalui penunjukan para pembantunya, juga melalui batas yang jelas antara patron dan klien. Pada era kolonial, para pemimpin patrimonial ini diberi keluasaan untuk menjalankan otoritas mereka di tingkat lokal.

Setelah kemerdekaan, ketika secara nasional telah diterapkan aturan yang mengikat mereka, para pemimpin patrimonial mulai mencari jalan bagaimana mereka terkoneksi dengan pemerintah pusat, untuk mempertahankan kekuasaannya tersebut. Semenjak itu hubungan patron-klien dalam kepemimpinan patrimonialisme tidak hanya terjadi antara masyarakat dengan pemimpin lokalnya, tetapi juga antara pemerintah lokal dengan pemerintah pusat.

Patrimonialisme desa cukup kuat pada saat Orde Baru, terutama hubungan patronase pemerintah desa kepada Pemerintah Pusat. Kuatnya patronase ini karena pemerintah Orde Baru memiliki kepentingan untuk menjadikan desa sebagai ajang mobilisasi politik. Menurut Antlov, bangunan patronase politik Orde Baru atas desa dilakukan dengan menggunakan Golkar dan tentara Angkatan Darat sebagai alatnya. Birokrasi ala Orde Baru di desa kemudian diterapkan secara mentah-mentah pada level birokrasi pemerintahan desa.

Sebagaimana Orde Baru yang sangat ketat mengontrol rakyatnya, pemerintah desa juga memberlakukan hal yang sama saat berhadapan dengan warganya. Kuatnya konsep pembangunan pada era Orde Baru yang sangat materialistik telah menggeser konsep tentang patrimonialisme yang semula bersandar kepada kekuatan tradisional bergeser pada sandaran materi. 
Dengan adanya pergeseran konsep tersebut, maka sandaran material menjadi penting dalam hubungan antara patron dengan klien; di mana pada akhirnya hanya patron yang sukses meraih keuntungan material yang akan terus bertahan menjadi pemimpin.

Dalam konteks inilah kemudian para kepala desa di era Orde Baru cerdik dalam mengakali bantuan pembangunan dari pemerintah pusat untuk memperkaya dirinya sendiri. Saat Orde Baru runtuh pada 1998, era kepemimpinan secara sentralistik berakhir. Kepemimpinan di era reformasi kemudian dijalankan dengan mengedepankan konsep desentralisasi, di mana daerah diberi kewenangan yang luas melalui otonomi untuk mengelola pemerintahannya sendiri. Hal-hal yang terkait dengan penyelenggaraan tata pemerintahan daerah dalam bingkai desentralisasi ini diatur oleh UU No. 22/1999 yang kemudian digantikan dengan UU No. 32/2004. Pengaturan tentang desa masuk dalam lingkup UU tentang pemerintah daerah tersebut, tidak diatur dalam UU tersendiri. Pengaturan tentang desa yang dimasukkan dalam UU tentang pemerintah daerah tersebut kemudian berkonsekwensi pada diposisikannya desa di bawah pemerintahan daerah. Mengacu pada UU No. 32/2004, otonomi hanya berhenti di kabupaten/kota. Dengan demikian, pengaturan lebih jauh tentang desa dilakukan oleh kabupaten/kota, di mana kewenangan Desa adalah kewenangan kabupaten/kota yang diserahkan kepada
Desa. Mengacu pada hal ini maka pada dasarnya kepemimpinan reformasi hanya menggeser patronase politik desa yang semula banyak berpatron kepada pemerintah pusat menjadi berpatron kepada pemerintah kabupaten/kota.

UU Desa diterbitkan dalam rangka untuk mengevaluasi praktik-praktik pengaturan tentang desa di bawah UU No. 32/2004. Dengan demikian, semangat yang dikedepankan oleh UU Desa adalah agar desa memiliki kewenangan yang relatif penuh untuk mengatur urusannya sendiri tanpa ada campur tangan secara berlebihan dari pemerintah kabupaten/kota, meskipun pada kenyataannya UU Desa masih saja memberikan kewenangan kepada pemerintah kabupaten yang dibingkai dalam konsep local self government. Pengaturan tentang

pemberian kewenangan pemerintah kabupaten/kota dalam urusan desa terasa pada norma-norma yang mengatur antara lain tentang peran bupati/walikota dalam mengesahkan dan menetapkan serta memberhentikan kepala desa dan anggota BPD; kewajiban kepala desa untuk mengonsultasikan kepada camat sebagai wakil bupati/walikota sebelum mengangkat perangkat desa; peran bupati/walikota melakukan evaluasi terhadap rancangan peraturan desa sebelum disahkan; kewajiban kepala desa untuk melaporkan pelaksanaan penyelenggaraan pemerintahan desakepada bupati/walikota; serta peran bupati/walikota sebagai pihak yang berwenang menyelesaikan sengketa 
dalam proses pemilihan kepala desa (pilkades).

$$
\text { Dengan model pengaturan }
$$
semacam itu, apakah kemudian UU Desa dapat dikatakan sebagai struktur yang mendukung bagi terselenggaranya demokrasi desa yang sesungguhnya, yakni demokrasi desa yang dijalankan oleh komunitas desa, demokrasi desa yang mementingkan masyarakat desa dari pada pemerintah kabupaten/kota. Dengan demikian, apakah implementasi UU Desa dapat mengubah desa menjadi demokratis setelah sekian lama terkungkung dalam praktik patrimonialisme politik? Analisis terhadap temuan penelitian tentang penyelenggaraan pemerintahan desa di tiga desa di tiga kecamatan di Kabupaten Bandung Barat dibingkai oleh pertanyaanpertanyaan ini.

Untuk melihat demokrasi desa yang relatif nyata, analisis ini diawali dengan pemaparan tentang praktik pemilihan kepala desa yang dijalankan di tiga desa. Dalam proses Pilkades, sebagai pihak yang diberikan kewenangan, desa melalui BPD telah membentuk panitia, di mana panitia tersebut telah melakukan berbagai prosedur Pilkades sebagaimana diatur oleh UU Desa. Dapat dikatakan bahwa panitia Pilkades telah menjalankannya secara piawai, mulai dari penjaringan calon, pendataan daftar pemilih, pelaksanaan pemilihan, hingga penghitungan suara. Namun demikian, kepiawaian tersebut tidak lepas dari peran pemerintah kabupaten, baik dalam bentuk peraturan daerah kabupaten maupun keterlibatan secara langsung. Perda kabupaten memainkan peran penting, karena dengan Perda panitia memiliki panduan operasional dalam pelaksanaan pilkades, misalnya dalam hal persyaratan calon serta tahapan tes untuk penjaringannya. Selain dalam bentuk Perda, keterlibatan kabupaten juga dilakukan secara langsung, terutama jika muncul masalah yang dihadapi oleh panitia.

Selain sebagai tempat berkonsultasi, kecamatan juga menjadi sumber informasi bagi panitia tentang tahapan tes yang diselenggarakan di kabupaten. UU Desa mengkonstruksi Pilkades sebagai rezim pemerintah daerah, sehingga wajar jika peran pemerintah kabupaten begitu kuat. Kuatnya rezim pemerintah daerah dalam proses Pilkades tercermin dalam beberapa pasal yang mengatur tentang pemilihan kepala desa, terutama pasal 37 ayat (6) yang menyatakan bahwa proses penyelesaian sengketa pilkades diselesaikan oleh bupati/walikota.

Merujuk pada ketentuan ini pula maka proses pengawasan terhadap pilkades juga menjadi ranah pemerintah kabupaten. Pada praktiknya, panitia pengawas pilkades dibentuk oleh kecamatan, sehingga segala hal yang terkait dengan pengaduan pelanggaran akan ditampung oleh tim ini sebagai representasi dari pemerintah kabupaten, dan berdasarkan tim inilah kemudian nantinya bupati menyelesaikan terjadinya proses sengketa pilkades. 
Data pada penelitian ini tidak menemukan adanya sengketa dalam pilkades, meskipun ada indikasi politik uang. Mengacu pada konsep strukturasi Giddens sebagaimana diuraikan sebelumnya, pada dasarnya UU dapat dianggap sebagai struktur. Terkait dengan hal ini Mukunda Lamsal menjelaskan bahwa struktur dapat berupa seperangkat aturan yang dengannya dapat menjadi penghalang bagi tindakan manusia, meskipun ia diciptakan oleh manusia sendiri sebagai sesuatu yang diterima dalam kehidupan sosial masyarakat.

Menurut Lamsal, Giddens merekomendasikan bahwa struktur secara universal berlaku tetap, meskipun dapat diubah terutama oleh akibat dari tindakan yang tidak disengaja; misalnya ketika orang sudah tidak lagi memperhatikan norma sosial, menggantinya, atau mereproduksinya menjadi suatu cara yang berbeda. Merujuk pada konsep strukturasi Giddens dan praktik penyelenggaraan Pilkades pada riset ini, kami pada suatu pendapat bahwa UU Desa dianggap sebagai struktur yang tidak menghalangi (constrain), tetapi justru menjadi struktur yang mendukung (enabling). Para agen, dalam hal ini panitia pilkades merasa nyaman dengan norma yang diatur dalam UU Desa, termasuk norma yang memberikan kewenangan kepada pemerintah kabupaten untuk berperan aktif dalam proses tersebut.

Tidak ada tindakan apapun dari panitia pilkades di luar dari apa yang diatur oleh UU Desa maupun Perda tentang Pilkades. Karena tidak ada tindakan tersebut maka dapat dipastikan tidak ada akibat yang ditimbulkan, terlebih sampai mengubah struktur yang ada. Seluruh tindakan panitia mengacu UU Desa dan Perda, serta melibatkan kabupaten (dan kecamatan) sebagai pihak yang merepresentasikan perda tersebut. Mengacu pada konsep di awal bahwa demokrasi desa pada dasarnya adalah perwujudan peran masyarakat secara aktif, dalam kasus Pilkades, peran tersebut masih kurang terlihat kecuali pada keterlibatan kepanitiaan. Kepanitiaan di bawah BPD telah mengasumsikan bahwa pilkades berada di bawah kewenangan masyarakat desa. Namun jika melihat praktiknya bahwa hampir keseluruhan proses masih banyak tergantung ada perda dan keterlibatan langsung kabupaten maupun kecamatan, menunjukkan bahwa peran masyarakat desa masih belum terlalu kuat di situ. Terlebih UU Desa juga tidak memberikan peluang bagi warga desa untuk terlibat dalam proses pengawasan Pilkades, karena pengawasan sepenuhnya tergantung pada kabupaten. Hal ini belum lagi ada beberapa seleksi dan persyaratan yang masih diselenggarakan oleh kabupaten.

Terkait dengan keterlibatan masyarakat dalam proses demokrasiselain dalam pilkades, UU UU Desa juga memberikan hak kepada masyarakatuntuk melakukan pengawasan terhadap penyelenggaraan pemerintahan desa serta 
diberikan kesempatan untuk mengikuti musdes untuk menyampaikan aspirasinya. Secara umum bentuk pengawasan ini belum terlihat. Laporan pertanggungjwaban kepala desa yang semestinya juga disampaikan kepada masyarakat, dalam studi yang kami lakukan belum cukup terlihat. Laporan pertanggungjawaban hanya disampaikan kepada bupati dan BPD. Dalam hal musdes, karena memang aturannya hanya memperkenankan unsur perwakilan, tidak semua warga dapat mengikutinya.

Namun demikian kesempatan warga dalam musyawarah sudah disediakan oleh pemerintah desa melalui perhelatan rutin sesuai dengan adat atau tradisi. Ada juga desa yang memanfaatkan rapat forum rapat tahunan anggota koperasi desa untuk mengumpulkan warga untuk memberikan umpan balik. Selain keterlibatan masyarakat, unsur lain yang penting yang menandai demokrasi desaadalah adanya BPD. Mengacu proses pembahasan UU Desa, BPD disebut- sebut sebagai lembaga yang memiliki peran untuk menjalankan fungsi check and balances terhadap pemerintah desa. BPD menurut UU Desa berfungsi untuk menampung dan menyalurkan aspirasi masyarakat desa, mengawasi kinerja kepala desa dan membahas serta menyepakati rancangan peraturan desa bersama kepala desa. Terkait dengan fungsinya ini maka BPD juga menjadi kunci bagi terselenggaranya penyelenggaraan pemerintahan desa yang baik. Keberadaan BPD dapat menjadi kontrol bagi kepala desa dalam menjalankan pemerintahan desa.

UU Desa mengatur bahwa anggota BPD merupakan wakil dari penduduk desa berdasarkan keterwakilan wilayah yang pengisiannya dilakukan secara demokratis. Dari segi pengisian keanggotaannya, BPD telah cukup dapat dilihat sebagai representasi dari wakil warga pada tiap wilayah atau dukuh, meskipun tidak dipilih oleh seluruh warga tetapi hanya perwakilan saja tiap RT-nya. Namun dalam hal menjalankan peran, BPD terlihat masih kurang optimal. Selain perannya sebagai penyelenggara Pilkades, peran BPD yang lain dalam konteks penyelenggaraan pemerintah desa yang demokratis masih belum terlihat.

Dalam hal menampung aspirasi warga, peran BPD masih belum terlihat secara jelas. Ini dapat dilihat misalnya dalam beberapa kasus, warga desa lebih cenderung menyampaikan aspirasinya kepada orang yang dianggap dekat dengan kepala desa, dengan harapan bahwa orang tersebut akan menyampaikannya kepada kepala desa. Ada juga warga yang mengadukan aspirasinya kepada RT atau RW.

Di Desa Sarinagen, justru aspirasi warga disampaikan kepada para penarik sampah yang mendatangi rumah penduduk tiap pagi. Para penarik sampah yang bekerja untuk BUMDes pengolahan sampah tersebut memang sengaja ditugaskan oleh Pemerintah Desa untuk 
menjalankan peran sebagai wakil desa untuk menampung aspirasi dan masalah warga. Menurut kepala desa Saringen, melalui mekanisme semacam ini pemerintah desa pernah mengatasi masalah warga yang terjerat rentenir. Demikian juga dalam menjalankan perannya sebagai pengawas pemerintah desa, BPD juga masih belum terlihat kinerjanya. Laporan pertanggungjawaban yang diserahkan oleh kepala desa hampir tidak pernah dibahas secara serius. Hampir tidak pernah ditemui BPD memberikan catatan terhadap laporan tersebut. Laporan pertanggungjawaban kepada bupati cenderung dianggap penting daripada kepada BPD, karena menganggap laporan kepada bupati akan berimplikasi pada persetujuan untuk pencairan dana desa berikutnya.

Dari data yang ada terungkap bahwa hubungan antara BPD dan Pemdes cenderung harmonis, tidak ada suatu wacana kritis yang dikedepankan oleh BPD dalam konteks penyelenggaraan pemerintahan desa. Kantor BPD juga biasanya berada di kantor pemerintah desa. Memang pernah diakui oleh BPD sendiri bahwa pihaknya melakukan pengawasan, namun yang dalam hal ini pengawasan yang dilakukan adalah dengan melakukan pengecekan terhadap proses pengerjaan pembangunan fisik, bukan pengawasan yang bersifatkomprehensif terkait dengan spesifikasi material dengan dokumen perencanaan misalnya. Kalaupun ini dapat disebut sebagai menjalankan peran pengawasan, pengawasan yang dilakukan masihterbilang kurang substantif.

Sebagian besar desa yang diteliti masih kurang produktif dalam memproduksi perdes, selain perdes wajib yaitu RPJMDes, APBDes dan RKPDes. Sedangkan perda-perda lain masih belum maksimal keberadaannya. Terkait dengan kurang optimalnya peran BPD ini ada hubungannya dengan kapasitas BPD yang kurang optimal. Secara kelembagaan, BPD cenderung kurang dijalankan dengan baik. Sebagai contoh, ada desa yang salah satu anggota BPD-nya tidak aktif hingga enam bulan, tidak ada tindakan apa-apa untuk mengatasi masalah tersebut. Di desa lain, BPD yang aktif hanya ketuanya saja.

Dalam kasus yang lain, misalnya dalam hal menangkap rekomendasi, pemerintah desa cenderung lebih banyak meminta rekomendasi kepada pemerintah kabupaten dari pada kepada BPD. Kasus kepala desa berumbung pada saat hendak membangun gedung pertemuan dari dana $A D D$, agar tidak terkena aturan tender harus diturunkan dananya di bawah Rp200 juta, harus konsultasi dengan BPMD. Pembangunan dijalankan setelah mendapatkan rekomendasi dari BPMD, sedangkan BPD yang mestinya menjalankan peran kontrol pemerintahan desa tidak dimintakan rekomendasi.

Mengacu pada data umum temuan hasil riset, memang dapat dikatakan demokrasi desa dalam bingkai UU Desa masih terbilang kurang optimal. "Keberhasilan" desa dalam menjalankan 
Pilkades lebih dipandang karena peran yang dominan dari kabupaten. Namun di sisi lain, anggapan mementingkan kabupaten dari pada masyarakat dan BPD maupun masyarakat mengganggu proses demokrasi dalam hal pelibatan warga dan wakil warga desa. Dari sini tampak bahwa pemerintah desa lebih banyak tergantung pada kabupaten. Kurang optimalnya BPD dalam menjalankan perannya bisa disebabkan karena kurangnya perangkat legal yang diterbitkan oleh kabupaten, sehingga BPD merasa gagap dalam menjalankan peran-peran tersebut.

\section{Kinerja Pemerintah Desa}

Memperhatikan seluruh proses demokrasi sebagaimana dipaparkan di atas bahwa ternyata peran kabupaten sangat terlihat di dalamnya. Dalam kasus Pilkades, kelancaran proses karena didukung oleh Perda dan keterlibatan langsung kabupaten. Dalam hal kurang optimalnya BPD dan masyarakat juga dipengaruhi oleh pemdes yang menganggap penting kabupaten. Belum ada Perda yang mengatur tentang peran BPD dalam menjalankan peran dan fungsinya. Dari sini sampai pada suatu pemahaman bahwa ketiadaan peraturan perda atau keterlibatan kabupaten justru menjadi penghalang bagi aksi-aksi inisiatif desa.

Di desa-desa yang ditelti inisiatif tidak muncul karena tidak ada dukungan perda. Kepala desa Mandalasari misalnya, merasa tidak cukup untuk menjalankan pemerintahan desa yang hanya didukung oleh lima orang perangkat desa. Namun disisi lain kepala desa tidak berani mengangkat sendiri perangkat desanya dengan alasan belum ada Perda yang mengatur tentang pengangkatan perangkat desa. Padahal secara normatif pengangkatan perangkat desa sudah cukup diatur dengan jelas. Sehingga tanpa ada Perda pun sebenarnya pengangkatan perangkat desa sudah dapat dilakukan dengan mengacu pada UU Desa. UU Desa menyatakan bahwa pengangkatan perangkat desa menjadi kewenangan kepala desa. Dalam proses pengangkatan ini, kepala desa hanya harus terlebih dahulu mengkonsultasikannya ke camat sebagai wakil bupati/walikota. Perangkat desa bertanggungjawab sepenuhnya kepada kepala desa. Jadi, meskipun pengangkatan perangkat desa menjadi diskresi kepala desa, namun tidak berani dijalankan tanpa ada perda kabupaten.

Ketiadaan aturan sebagai constraint juga tampak pada apa yang disampaikan oleh kepala desa Nangerang yang menyatakan bahwa dirinya merasa terhambat inovasinya karena ketiadaan aturan. Menurutnya, ketiadaan aturan membuatnya tidak berani untuk membeli aset desa berupa tanah yang dapat disewakan untuk penanaman palawija. Jika desa dapat menyewakan lahan seluas 10 hektar, maka desa akan mendapatkan PADes Rp 10 juta tiap bulan. Kalau ini berjalan, menurutnya desa tidak perlu mengandalkan APBD lagi. Self governing community sebagaimana yang telah dikonstruksi oleh UU Desa masih belum 
dipahami dan diimplemenasikan secara optimal dalam proses demokrasi desa. Dalam praktiknya, konsep local self government masih cukup dominan.

Pemahaman terhadap konsep ini juga ternyata terjadi dalam hal kinerja pemerintahan desa. Namun demikian, ada inisiatif yang secara umum dilakukan oleh pemerintah desa sebagai semangat menjalankan fungsi self governing community. Inisiatif ini terlihat dalam upaya pemerintah desa menjalankan perannya sebagai mediator dalam kasuskasus persengketaan di antara warga desa. Ada kemauan yang kuat dari pemerintah desa untuk tidak membawa sengketa antar warga ke ranah hukum, namun cenderung ingin diselesaikan secara mandiri di tingkat desa. Pemerintah Sarinagen bahkan melembagakan peran ini dengan cara mendirikan lembaga bantuan hukum di tingkat desa. Terkait dengan kinerja pemerintahan desa, secara umum stakeholder di desa memahami bahwa tolok ukur keberhasilan kinerja diindikasikan pada berlangsungnya pembangunan secara fisik. Dengan demikian kinerja pemerintah desa lebih banyak terfokus pada pembangunan fisik, antara lain pembangunan gedung pertemuan, pengerasan jalan, semenisasi selokan, dsb.

Pembangunan ekonomi warga desa yang antara lain dilakukan dengan pendirian BUMDes, meskipun sudah dilakukan tetapi terkesan belum dijalankan secara maksimal. Belum dijumpai pengelolaan BUMDes secara pasti dan belum ada skema yang diterapkan untuk meningkatkan profit BUMDes sehingga dapat meningkatkan ekonomi warga.

Namun di luar itu, secara spesifik pemerintah desa Sarinagen telah menunjukkan upaya untuk menjalankan pembangunan di luar pembangunan fisik. Beberapa hal yang dijalankan oleh Pemdes Sarinagen antara lain menerapkan program satu rumah satu sarjana. Melalui program ini, Pemdes memberikan beasiswa kepada warga desa yang kurang mampu sehingga dapat menyelesaikan pendidikannya hingga jenjang sarjana. Dukungan pembiayaan warga diwujudkan dalam skema asuransi, di mana preminya menjadi tanggungjawab Pemdes untuk membayarnya. Uang asuransi nantinya dapat dicairkan pada saat siswa masuk ke jenjang pendidikan berikutya. Dalam bidang kesehatan, Pemdes Sarinagen menerapkan program Desa Bebas Empat Masalah Kesehatan (DB4MK), yaitu balita gizi buruk, kematian balita, kematian ibu melahirkan dan kasus demam berdarah dengue (DBD). Untuk mengatasi masalah kematian ibu hamil, Pemdes melakukan pelayanan paripurna, melalui pemberian pengantar kepada ibu hamil yang tidak mampu untuk dilayani secara penuh oleh rumah bersalin.

Untuk masalah gizi buruk, Pemdes punya program pemanfaatan lahan pekarangan untuk menanam sayur dan memelihara ikan. Terkait dengan perlindungan sosial, Pemdes menerapkannya sebagai jaring pengaman 
terakhir, karena jaring pengaman yang dilakukan oleh pemerintah pusat seringkali tidak dapat menjangkau warga karena kekacauan data. Warga yang tidak dapat dilayani oleh program seperti Jamkesmas maupun Jamkesda dapat diselamatkan melalui jaring pengaman sosial di desa. Dukungan pembiayaan untuk menjalankan seluruh program tersebut tidak sepenuhnya berasal dari anggaran desa, tetapi didukung juga oleh dana-dana Corporate Social Responsibility (CSR) perusahaan yang beroperasi di Sarinagen. Untuk perlindungan sosial kesehatan, Pemdes bekerja sama dengan rumah sakit yang dikelola oleh BAZNAS.

Pembayaran premi asuransi pendidikan separuh dibayai oleh Pemdes sisanya merupakan dana CSR Perusahaan Asuransi Bumiputera. Sedangkan untuk pelayanan kehamilan dan persalinan separuh biayanya ditanggung oleh Pemdes, sisanya ditanggung oleh CSR rumah-rumah bersalin. Dengan memperhatikan seluruh kinerja yang dilakukan oleh Pemdes Sarinagen tampak bahwa semua itu tidak tergantung dari adanya Perda, tetapi berasal dari keinginan untuk menjalankan pembangunan desa. Dengan demikian ada atau tidaknya perda, bagi Sarinagen bukan halangan, karena pada dasarnya desa telah diberikan kewenangan yang luas oleh UU Desa.

\section{KESIMPULAN}

Meskipun desa telah diberikan kewenangan luas oleh UU Desa untuk menyelenggarakan urusannya sendiri, namun dalam praktiknya kebanyakan dari desa yang diteliti masih cenderung tergantung dengan pemerintah kabupaten. Terkait dengan pelaksanaan demokrasi desa, ruang artikulasi warga masih belum difungsikan secara optimal. BPD, sebagai wahana representasi warga belum berperan secara optimal, serta tidak ada upaya untuk memperkuat peran-peran tersebut, baik dari BPD sendiri maupun oleh warga. Sehingga bisa dikatakan tata kelola pemerintahan desa pasca implementasi Undang-Undang Desa bisa dikatakan tidak banyak mengalami perubahan.

Kewenangan desa untuk membentuk Perdes juga masih belum dimanfaatkan secara penuh. Tidak banyak perdes yang terbit, selain perdes-perdes utama seperti APBDes. Dengan kewenangan penuh semestinya makin banyak perdes yang diterbitkan karena konsekwensinya akan banyak urusan yang diatur oleh desa itu sendiri. Mindset kepala desa tampaknya sudah menunjukkan hal positif, dalam artian bahwa kepala desa sudah mulai membuka ruang demokrasi, namun demikian butuh keberanian untuk menjalankannya tanpa perlu kekhawatiran adanya intervensi dari pemerintah kabupaten. Rendahnya kualitas demokrasi berimbas pada kinerja pemerintah desa. Kinerja pemerintah hanya dipahami sebagai kinerja pembangunan 
secara fisik. Suara-suara dari warga terhadap kebutuhan pembangunan lain selain pembangunan fisik masih kurang diakomodir. Dalam kasus Sarinagen, pembangunan yang dijalankan lebih cenderung karena kehendak dan inisiatif dari kepala desanya. Meskipun tetap mengacu pada kehendak warga yang disampaikan dalam Musdes, namun porsinya relatif kecil.

Kinerja pemerintah desa yang baik diharapkan mendapatkan kepercayaan warga, dari situ kesadaran warga terhadap demokrasi desa akan tumbuh. Desa menjadi topik yang sangat kuat baik di media, maupun pembicaraan masyarakat, topik yang dibincangkan terkait kesiapan desa dalam menerima dan mengelola dana desa yang diberikan oleh pemerintahpusat, karena hal ini baru terjadi sejak adanya UU Desa, dana desa sangat dibutuhkan dalam rangka membiayaikegiatan yang dibutuhkan oleh desa. Namun dalam proses penerimaan dana tersebut masih banyak mendapatkan catatan karena tugas delegasi yang diberikan oleh kabupaten kepada camat belum dibarengi dengan pemberian tugas dan petunjuk dalam melaksanakan tugas tersebut.

Dominasi camat dalam menentukan arah pembangunan desa menjadi kuat ketika tanpa petunjuk yang diberikan oleh kabupaten/kota, sementara pembangunan desa merupakan pilar kemajuan bagi kabupaten/kota. Identifikasi dan dokumentasi terhadap aset desa menjadi sebuah keharusan, ketika aset desa diketahui maka kebijakan pembangunan bisa berpijak dan mengacu pada aset yang dimiliki desa, tanpa aset, maka desa terancam tidak berdaya. Ketidakjelasan aset akan membuat desa terus meraba- raba tentang kekayaan apa saja yang dimilikinya. Sehingga saat perumusan perencanaan pembangunan pengelolaan dan pemanfaatan terhadap aset tersebut tidak masuk dalam kerangka kerja desa, Maka saatnya pemerintah kabupaten/kota memfasilitasi

dan memberikan pendampingan kepada pemerintah desa dalam mengindentifikasi dan menemukenali serta mendokumentasikan aset yang dimiliki oleh desa dalam mencapai kesejahteraan bersama.

\section{DAFTAR PUSTAKA}

Adam, Julia "The Rule of The Father: "Patriarchy and Patrimonialism in Early Modern Europe".

Antlov, Hans dan Sutoro Eko, 2012, "Village and Sub-District Functions in Decentralized Indonesia (Paper)"

Antlov, Hans, 2002, "Negara dalam Desa: Patronase Kepemimpinan Lokal' (Edisi Terjemahan oleh Pujo Semedi. Yogyakarta: LAPPERA.

Camic, Charles, Philip S. Gorski, dan David M. Trubele, 2005, "Max Webers Economy and Society: $A$ Critical Companion", Standford University Press.

Direktorat Pemerintahan Desa dan Kelurahan Direktorat Jenderal Pemberdayaan Masyarakat danDesa Departemen Dalam Negeri, 2007, "Naskah Akademik Rancangan Undang-undang tentang Desa. Jakarta. 
Himalayan Journal of Sociology \& Anthropology Vol-V, 2012.

Jacqueline. A.C. Veli, 2008, "Uma Politics: An Ethnography of Democratization in West Sumba, Indonesia 1986 2006". Leiden: KITLV Press.

Lamsal, Mukunda, 2012, "The Structuration Approach of Anthony Giddens".

Li, Tania Murray, 2012, "The Will to Improve: Perencanaan, Kekuasaan, dan Pembangunan di Indonesia (Terjemahan Hery Santoso dan Puji Semedi. Jakarta: Marjin Kiri.

Peraturan Bupati Bandung Barat No, 4 Tahun 2018 tentang Pengalokasian dan Pembagian Alokasi Dana Desa Tahun Anggaran 2018.

Peraturan Bupati Bandung Barat No. 8 Tahun 2017 tentang Petunjuk Pemilihan Kepala Desa.

Peraturan Daerah Bandung Barat No. 20 Tahun 2009 tentang Sumber Pendapatan Desa.

Peraturan Pemerintah No. 47 Tahun 2015 tentang Perubahan atas Peraturan Pemerintah No. 43 Tahun 2014 tentang Peraturan Pelaksanaan Undang-undang No. 6 Tahun 2014 tentang Desa. 